\title{
Techno-economical analysis of single pressure exhaust gas waste heat recovery systems in marine propulsion plants
}

\author{
Gerasimos Theotokatos and George Livanos \\ Department of Naval Architecture \\ Faculty of Technological Applications, TEI of Athens \\ Ag. Spyridonos Str., 12210 Egaleo, GREECE \\ (corresponding author: G. Theotokatos, email: mtheot@teiath.gr)
}

\begin{abstract}
In the present paper, the waste heat recovery (WHR) installations used for the production of saturated steam and electric power for the cases of a two-stroke and a four-stroke engine propulsion plant of a typical merchant ship are investigated. The examined waste heat recovery system is considered to be of the single steam pressure type with an external heat exchanger for the heating of feed water entering into the boiler drum. The option of using the engine air cooler for heating the feed water was also examined. The waste heat recovery installation was modeled under steady state conditions and the derived WHR installation parameters for various engine loads are presented an analyzed. Furthermore, using the simulation results, the improvement of energy efficiency design index (EEDI) of the examined ship is calculated and the impact of the WHR on the ship EEDI is discussed. In addition, following the technical evaluation of the alternative options for the ship propulsion plant, an economic study was performed for a typical ship voyage. The derived results were presented and discussed leading in conclusions for the most techno-economical propulsion system configuration.
\end{abstract}

Keywords: waste heat recovery, marine propulsion systems, EEDI, techno-economical analysis

\section{INTRODUCTION}

The raising of fuel oil prices throughout the last years, as well as the increased concern for the reduction of the carbon dioxide $\left(\mathrm{CO}_{2}\right)$ gaseous emissions owing to environmental issues, have resulted in the proposals of using mechanical layouts for recovering part of the main engine(s) exhaust gas energy and producing thermal and electric power in marine powerplants. Taking into account the efficiency of 
the marine Diesel engines used onboard ships for propulsion and electricity generation (about $50 \%$ for two-stroke engines and slightly lower for four-stroke engines), a considerable amount of energy is wasted to the ambient. A portion of that energy could be recovered to cover part of the ship thermal power and/or electric power requirements. Example of wasted energy is the ship main and auxiliary engines exhaust gas energy, which accounts for about $25 \%$ of the energy delivered to the engine with the fuel or equivalently about $40-60 \%$ of the engine produced power. In addition, the exhaust gas temperature is high enough, so that the exhaust gas wasted energy can be recovered using techno-economically efficient installations.

Usually, two typical options are used for exhaust gas waste heat recovery (WHR) onboard ships [1,2]: a) the installation for the production of saturated steam indented for covering the thermal power requirements of the ship (heating services) and b) the installation for production of both saturated steam and superheated steam. The superheated steam is expanded in a steam turbine producing mechanical energy to drive an electric generator. For the WHR installations of case (b), simple steam pressure systems or more complicated double steam pressure systems can be used $[1,3,4]$. In the latter case, the installation acquisition cost is higher, but greater amount of electric power is produced by recovering greater amount of the wasted heat, and therefore, the installation payback period can be kept in a rational time. The double steam pressure systems often require the recovery of an additional amount of energy from the other ship waste heat sources, e.g. from the engine air cooler or the engine jacket water cooler. In such cases, the recovered heat is used for preheating the low and high pressure water (thus replacing the boiler preheaters). For further increasing the overall efficiency of ship propulsion plant (and thus further reducing the $\mathrm{CO} 2$ gaseous emissions), more complicated installations have been designed comprising an exhaust gas turbine in addition to the steam turbine and exhaust gas boiler [5-9]. Previous studies concerning the design, optimization and modeling of WHR installations have been presented in $[3-5,9-15]$.

The last years, the International Maritime Organization (IMO) introduced the Energy Efficiency Design Index (EEDI) to measure the $\mathrm{CO}_{2}$ efficiency of merchant ships [16-17]. The EEDI is a simple formula that estimates $\mathrm{CO}_{2}$ output in grams per tonne and nautical mile. The numerator of this formula represents $\mathrm{CO}_{2}$ emissions after accounting for innovative machinery and electrical energy efficiency 
technologies that are incorporated to the design, whereas the denominator is a function of the speed, capacity and ship specific factors.

The present work is focused on the performance investigation of the WHR system utilizing the exhaust gas of the propulsion engine of a typical handymax class bulk carrier. Two cases for the ship propulsion installation are considered. In the first case, a two-stroke marine Diesel engine, which is directly connected to the ship propeller via the ship shafting system, is used as the main engine of the ship. In the second case, a four-stroke marine Diesel engine connected to the ship propeller via a gear box/clutch unit and shaft is used as the ship propulsion engine. The engine efficiency is higher in the case of two-stroke engine, resulting in lower exhaust gas temperature (and thus lower available energy content in the exhaust gas). In the case of four-stroke engine, lower values of the propulsion plant efficiency is obtained taking into account the lower efficiency of the four-stroke marine diesel engine and the efficiency of the shafting system, which includes a gearbox/clutch unit.

The WHR system is considered to be of the single steam pressure type with external heat exchanger for heating the feed water entering into the boiler drum. The option of heating the feed water using the engine air cooler is also investigated. The WHR system is used for the production of saturated steam for covering the requirement of the ship in thermal power for the ship heating services, and electric power for covering partly or totally the ship electric power demands. The WHR system was modeled under steady state conditions for various engine loads in the range from $50 \%$ to $100 \%$ of the engine maximum continuous rating (MCR) point. The derived results are analyzed and the effect of the WHR system operating parameters on the produced electric power and the ship powerplant efficiency improvement is discussed. In addition, the EEDI of the considered ship is calculated and the influence of WHR system on the variation of ship EEDI is commented. The economical feasibility of the WHR system was also evaluated by calculating the payback period and the internal rate of return for a range of HFO fuel prices and two ship operating scenarios-one intensive and one less intensive.

\section{DESCRIPTION OF THE WHR INSTALLATION}

A typical WHR installation of single pressure for saturated and superheated steam production is shown in Figure 1. The exhaust gas boiler consists of three stages; the economizer (preheater), the evaporator 
and the superheater. The feed water is pumped by the feed water pump into the water/steam drum. In the installation shown in Figure 1, an external heat exchanger is used for preheating the feed water. As an option, the high temperature stage of the engine air cooler could be also used for initially preheating the feed water. The feed water having temperature in the range from 50 to $120^{\circ} \mathrm{C}$ enters into the heat exchanger, where it is heated reaching a temperature value slightly lower than the water saturation temperature $\left(165^{\circ} \mathrm{C}\right.$ for pressure $\left.7 \mathrm{bar}\right)$, and subsequently enters into the water/steam drum. The heating medium is the saturated water contained in the drum, which is pumped by the economizer circulating water pump, enters the heat exchanger heating the feed water and leaves the heat exchanger with lower temperature. In order for the temperature of the circulating water exiting the external heat exchanger and entering into the economizer to be kept in the range of $130^{\circ} \mathrm{C}$, the flow rate of the circulating pumps must be three or four times the flow rate of feed water. The circulating water exiting the economizer returns to the drum having temperature approximately equal to the saturation temperature corresponding to the drum operating pressure.

An additional circulating pump is used to circulate the water through the evaporation section of the boiler. The pump flow rate should be two to four times the flow rate of feed water, so that the integrity of the evaporator section is not jeopardized due to overheating in cases where the evaporator tubes run out of water. Inside the tubes of the evaporation section, a portion of saturated water is evaporated and saturated steam is produced. The saturated water/steam mixture exiting the boiler returns into the drum, where the saturated steam is separated from the water and is accumulated in the upper part of the drum. A portion of the saturated steam is used to cover the ship heating services, whereas the rest is advanced into the superheater section of the boiler.

The temperature of the superheated steam exiting the exhaust gas boiler depends on the temperature of the exhaust gas entering the boiler. The temperature difference between the two fluid flows (i.e. the exhaust gas entering the boiler superheater section and the superheated steam exiting the boiler) is required to be greater than or equal to $20^{\circ} \mathrm{C}$ [1]. The superheated steam exiting the boiler enters into the steam turbine stages of turbogenerator, where it expands producing mechanical power and driving the electric generator. Thus, electric power is produced, which can partly or entirely cover the ship needs in electricity depending on the installation operating conditions. The steam pressure downstream of the steam turbine must be kept in such levels so that the steam quality is in the region of $90 \%$, otherwise 
moisture drops may be formed in the final stages of steam turbine, which can cause wear of the steam turbine blades. The steam exiting the steam turbine is advanced to the condenser, where it condenses by the usage of sea water. The condenser absolute pressure is set in the range from 0.05 bar to 0.08 bar, so that the steam turbine expansion ratio is as high as possible and the maximum mechanical work is produced in the steam turbine. In such condenser pressure range, the temperature of cooling sea water at condenser inlet is required to have temperature in the region from $10^{\circ} \mathrm{C}$ to $25^{\circ} \mathrm{C}$, which normally occurs. The condensate is pumped into the feed water tank (hot well) through the condensate pump. In case where surplus amount of saturated steam is produced, it is also forwarded into the surplus steam condenser where it converts to condensate water, which subsequently is pumped to the feed water tank.

In the case of heating the feed water using the engine air cooler, additional piping is required, so that the feed water is pumped to the high temperature stage of the engine air cooler, where it is heated by the simultaneously cooling of the compressed air. The air is further cooled in the low temperature stage of the engine air cooler using the cooling fresh water. In that case, lower heat is required in the boiler economizer, resulting in greater amount of heat available in the other sections of the boiler. However, as the temperature of feed water (heated in engine air cooler) increases, lower amount of heat is required in the economizer, and therefore the temperature difference at pinch point decreases. In such case, the increase of the exhaust gas temperature at the boiler outlet may be required, so that the boiler minimum temperature difference is kept above a critical value $\left(10-15^{\circ} \mathrm{C}\right)$, thus ensuring the unproblematic function of the boiler.

\section{MODELING OF THE WHR INSTALLATION}

The governing equations for the mathematical modeling of the WHR installation under steady state conditions are derived by applying the mass and energy conservation equations in the various components of the installation.

The heat transferred to the steam/water in the exhaust gas boiler is given by:

$$
\dot{Q}_{b}=\eta_{b} \dot{m}_{g} c_{p_{-} g}\left(T_{g_{-} i}-T_{g_{-} o}\right)
$$

where $\dot{m}_{g}$ is the exhaust gas mass flow rate, $c_{p g}$ is the exhaust gas mean specific heat at constant pressure, $T_{g_{-}}$is the temperature of the exhaust gas entering into the boiler, $T_{g_{o} o}$ is the temperature of the 
exhaust gas exiting the boiler, and $\eta_{b}$ is the boiler efficiency that is in the order of $98-99 \%\left(1-\eta_{b}\right.$ is the boiler heat transfer losses).

Considering that the water exits the economizer section in saturated condition, the energy balance in the boiler gives:

$$
\begin{aligned}
\dot{Q}_{b}= & \dot{Q}_{e c}+\dot{Q}_{e v}+\dot{Q}_{s h}= \\
& \dot{m}_{c w_{-} e c}\left(h_{w}-h_{c w_{-} e c_{-} i}\right)+\dot{m}_{c w_{-} e v}\left(h_{w}-h_{c w_{-} e v_{-} i}\right)+\dot{m}_{s}\left(h_{s}-h_{w}\right)+\dot{m}_{s h}\left(h_{s h}-h_{s}\right)
\end{aligned}
$$

where $\dot{m}_{c w_{-} e c}$ is the economizer circulating water mass flow rate, $\dot{m}_{c w_{-} e v}$ is the evaporator circulating water mass flow rate, $\dot{m}_{s h}$ is the superheated steam mass flow rate, $\dot{m}_{s}$ is the mass flow rate of the saturated steam produced in the evaporator, $h_{c w_{-} e_{-} i}$ is the specific enthalpy of the circulating water entering into the economizer (which is exiting from the external heat exchanger), $h_{s h}$ is the specific enthalpy of the superheated steam exiting the boiler, $h_{c w_{-}{ }_{-} \_}$is the specific enthalpy of the circulating water entering into the evaporator (exiting the evaporator circulating water pump), $h_{w}$ and $h_{s}$ are the specific enthalpies of saturated water and steam exiting the evaporator, respectively.

The mass balances in the feed water tank and in the boiler drum provide:

$$
\dot{m}_{f w}=\dot{m}_{s}=\dot{m}_{s h}+\dot{m}_{s_{-} h s}
$$

where $\dot{m}_{f w}$ is the feed water mass flow rate and $\dot{m}_{s_{-} h s}$ is mass flow rate of the saturated steam required for covering the ship heating services.

Taking into account the Equation 3 and applying the energy balance in the external heat exchanger, we get:

$$
\dot{m}_{c w_{-} e c}\left(h_{c w_{-} e c_{-} p d}-h_{c w_{-} e c \_i}\right)=\dot{m}_{s}\left(h_{f w_{-} d_{-} i}-h_{f w_{-} p d}\right)
$$

where $h_{c w \_c \_p d}$ is the specific enthalpy of the economizer circulating water entering into the external heat exchanger, $h_{f w p d}$ is the specific enthalpy of the feed water entering into the external heat exchanger (exiting the feed water pump or engine air cooler), and $h_{f w_{-}{ }_{-} i}$ is the specific enthalpy of the feed water exiting the external heat exchanger and entering into the drum.

The specific enthalpy of the feed water entering the drum is derived by manipulating the equation that defines the heat exchanger effectiveness, $\eta_{H E}[18]$ : 


$$
h_{f w_{-} d_{-} i}=h_{f w_{-} p d}+\eta_{H E}\left(h_{c w_{-} e c_{-} p d}-h_{f w_{-} p d}\right)
$$

By applying the energy conservation in the water/steam drum and after some manipulation, we get:

$$
\left(\dot{m}_{c w_{-} e c}+\dot{m}_{c w_{-} e v}\right)\left(h_{c w}-h_{w}\right)=\dot{m}_{s}\left(h_{f w_{-} d_{-} i}-h_{w}\right)(6)
$$

where $h_{c w}$ is the specific enthalpy of water contained in the drum.

The required power for each pump of the installation can be calculated using the following equation:

$$
P_{i}=\dot{m}_{i}\left(h_{i_{-} p d}-h_{i_{-} p u}\right)=\dot{m}_{i} \Delta p_{i} /\left(\eta_{i} \rho_{i}\right)
$$

where $\dot{m}_{i}$ is the pump mass flow rate, $h_{i, p u}$ and $h_{i p d}$ are the fluid specific enthalpies upstream and downstream the pump, respectively, $\Delta p_{i}$ is the pump pressure increase; $\eta_{i}$ is the pump efficiency, $\rho_{i}$ is the fluid density, and $i=f w$ for the feed water pump, $i=c w_{-} e c$ for the economizer circulating water pump, $i$ $=c w_{-} e v$ for the evaporator circulating water pump, $i=c$ for the condensate water pump, and $i=c \_s w$ for the condenser sea water pump.

The energy balance in the feed water tank gives:

$$
\dot{m}_{f w} h_{f w}=\dot{m}_{s h} h_{c_{-} p d}+\dot{m}_{s_{-} h s} h_{w_{-} h s}+\dot{Q}_{f w}
$$

where $h_{w_{-} h s}$ is the specific enthalpy of the condensate water returning from the ship heating services to the feed water tank, $h_{c \_p d}$ is the specific enthalpy of the condensate water exiting the condensate pump and entering the feed water tank, and $\dot{Q}_{f w}$ is the thermal power used for heating the feed water tank.

In the case where the feed water tank is heated by using saturated steam, the thermal power added to the feed water is calculated by:

$$
\dot{Q}_{f w}=\dot{m}_{s_{-} f w}\left(h_{s}-h_{w}\right)
$$

where $\dot{m}_{s f f}$ is the mass flow rate of the saturated steam required for heating the feed water to the predetermined temperature.

In the case where the high temperature stage of the engine air cooler is used for heating the feed water tank, the thermal power added to the feed water is given by:

$$
\dot{Q}_{f w}=\eta_{\mathrm{ac}} \dot{m}_{\mathrm{a}} c_{p_{-} \mathrm{a}}\left(T_{\mathrm{ac}_{-} H T_{-} i}-T_{\mathrm{ac}_{-} H T_{-} o}\right)
$$


where $\dot{m}_{\mathrm{a}}$ is the air mass flow rate entering the engine air cooler, $c_{p_{\mathrm{a}}}$ is the mean specific heat at constant pressure of the air in the high temperature stage of the engine air cooler, $T_{\text {ac } \_H T_{-} i}$ is the temperature of the air entering the high temperature stage of the engine air cooler, $T_{\mathrm{ac}_{-} H T_{-} o}$ is the temperature of the air exiting the high temperature stage of the engine air cooler and and $\eta_{\mathrm{ac}}$ is the air cooler efficiency that is in the order of $99.5 \%\left(1-\eta_{\mathrm{ac}}\right.$ is the air cooler heat transfer losses $)$.

Taking into account the superheated steam temperature and pressure drops in the pipe connecting the superheater outlet to the steam turbine, the specific enthalpy of the superheated steam entering the steam turbine is calculated. The superheated steam is expanded in the steam turbine of turbogenerator (steam turbine and electric generator), thus providing the required mechanical work to drive the electric generator. The produced electric power is calculated by:

$$
P_{e l}=\dot{m}_{S h}\left(h_{S T_{-} i}-h_{S T_{-} o_{-} i s}\right) \eta_{T G} f_{b} f_{T} f_{L}
$$

where $h_{S T_{-} i}$ is the specific enthalpy of the superheated steam entering the steam turbine, $h_{S T_{-} o_{-} \text {is }}$ is the specific enthalpy of the steam exiting the steam turbine in the case where the steam expands isentropically, $\eta_{T G}$ is the efficiency of the turbogenerator, and $f_{b}, f_{T}, f_{L}$ are correction factors for the steam turbine back pressure, steam temperature and steam turbine load, respectively. Data for the estimation of turbogenerator efficiency and the correction factors are given in [1].

The specific enthalpy of the steam exiting the steam turbine is calculated by:

$$
h_{S T_{-} o}=h_{S T_{-} i}-\eta_{S T}\left(h_{S T_{-} i}-h_{S T_{-} o_{-} i s}\right)
$$

where $\eta_{S T}=\eta_{T G} /\left(\eta_{G} \eta_{m}\right)$ is the steam turbine efficiency, $\eta_{G}$ is the generator efficiency, and $\eta_{m}$ is the turbogenerator mechanical efficiency.

The heat rate that has to be transferred from the steam to the cooling medium of the condenser (usually sea water) is given by:

$$
\dot{Q}_{c}=\dot{m}_{s h}\left(h_{S T_{-} o}-h_{c_{-} w}\right)
$$

where $h_{c_{-} w}$ is the specific enthalpy of the condensate water exiting the condenser.

The mass flow rate of the condenser sea water pump is calculated by:

$$
\dot{m}_{c_{-} s w}=\dot{Q}_{c} /\left(c_{p_{-} s w} \Delta T_{s w}\right)
$$


where $c_{p_{-} s w}$ is the condenser sea water specific heat, and $\Delta T_{s w}$ is the temperature increase of the sea water in the condenser.

The set of equations (1-14) is solved in order for the WHR system parameters to be calculated. The required parameters that are provided as input include: a) the engine exhaust gas mass flow rate, temperature and air/fuel equivalence ratio as well as the temperature of the air exiting the turbocharger compressor, b) the pressure of the drum water/steam, c) the pressure and temperature of the feed water tank, d) the way of feed water heating (no heating, using saturated steam or using the engine air cooler) e) the pressure losses in the various boiler sections and the piping of the WHR installation, f) the ratio of the economizer circulating water to the produced saturated steam mass flow rates and the ratio of the evaporator circulating water to the produced saturated steam mass flow rates, g) the mass flow rate of saturated steam required for the ship heating services, h) the boiler efficiency, the pumps efficiency, the external heat exchanger effectiveness and the air cooler efficiency, i) the temperature of superheated steam exiting the boiler, j) the temperature drops at various sections of the WHR installation, $\mathrm{k}$ ) the condenser pressure, and 1) the algebraic equations for the calculation of the properties of water/steam, exhaust gas and air.

The calculation output parameters include a) the superheated steam, saturated steam, feed water and condensate water mass flow rates, b) the water, steam and gas state (pressure, temperature specific enthalpy, etc) in all the WHR system points, the heat transfer rates in the WHR system parts, the turbogenerator and steam cycle efficiencies, and the produced electric power.

The first estimation for the mass flow rate of the superheated steam, which is required as input for starting the calculation procedure, is calculated using the following equation derived considering the ideal Rankine cycle:

$$
\dot{m}_{s h}=\frac{\eta_{b} \dot{m}_{g} c_{p_{-} g}\left(T_{g_{-} i}-T_{g_{-} o}\right)-\dot{m}_{s_{-} h s}\left(h_{s}-h_{f w}\right)}{h_{s h}-h_{f w}}
$$

The minimum temperature difference (pinch point) is calculated using the following equation, which is derived using the energy balance in the evaporator and superheater sections of the boiler:

$$
\Delta T_{p p}=T_{g_{-i} i}-\frac{\dot{Q}_{e v}+\dot{Q}_{s h}}{\eta_{b} \dot{m}_{g} c_{p_{-} g}}-T_{s}
$$


where $T_{s}$ is the temperature of saturated steam/water.

The increase in the ship propulsion installation efficiency is calculated by the following equation:

$$
\Delta \eta=\left[\left(P_{e l}-\sum_{\text {pumps }} P\right)+\dot{m}_{s_{-} h s}\left(h_{s}-h_{w}\right)\right] /\left(\dot{m}_{f} H_{L}\right)
$$

where $\dot{m}_{f}$ is mass flow rate of the engine fuel, and $H_{L}$ is the fuel lower heating value.

\section{IMO ENERGY EFFICIENCY DESIGN INDEX}

The Marine Environmental Protection Committee (MEPC) of the IMO recognized the need to develop an energy efficiency design index for new ships in order to stimulate innovation and technical development of all elements influencing the energy efficiency of a ship from its design phase [16].

The attained new ship Energy Efficiency Design Index (EEDI) is a measure of ships $\mathrm{CO}_{2}$ efficiency and in the case of a typical bulk carrier (no ice-class) is calculated by the following formula:

$$
E E D I=\frac{P_{M E} \cdot C_{F M E} \cdot S F O C_{M E}+P_{A E} \cdot C_{F A E} \cdot S F O C_{A E}}{D W T \cdot V_{r e f}}-\frac{f_{e f f} \cdot P_{A E e f f} \cdot C_{F A E} \cdot S F O C_{A E}}{D W T \cdot V_{r e f}}
$$

where EEDI is in $\mathrm{g} \mathrm{CO}_{2} / \mathrm{t} / \mathrm{NM}, C_{F}$ is a non-dimensional conversion factor between fuel consumption (in $\mathrm{g}$ ) and $\mathrm{CO}_{2}$ emission (also in $\mathrm{g}$ ) and is based on fuel carbon content, $C_{F}=3.206 \mathrm{~g} \mathrm{CO}_{2} / \mathrm{g}$ fuel for the case of Diesel Gas/Oil (this value of $C_{F}$ were used throughout this study since the majority of Diesel engine testing for processing the Engine International Air Pollution Prevention (EIAPP) certificates are performed using DMX through DMC grade distillates), $M E$ and $A E$ refer to the main and auxiliary engine(s), respectively, $D W T$ is the deadweight in case of the dry cargo carrier, $P_{M E}$ is defined as the $75 \%$ of the rated installed power (MCR) of the main engine, after having deducted any installed shaft generator power, $P_{A E}$ is the required auxiliary engine power to supply normal maximum sea load including necessary power for propulsion/machinery systems but excluding any other power e.g. ballast pumps, thrusters, cargo gear etc, in the condition where the ship engaged in voyage at the speed $V_{r e f}$ under the design loading condition, $P_{A E e f f}$ is the auxiliary power reduction due to innovative electrical energy efficient technology (e.g. WHR) measured at $P_{M E}, f_{\text {eff }}$ is the availability factor of each innovative energy efficiency technology, which should be 1.0 for waste energy recovery system according to [16]; 
$S F O C_{M E}$ and $S F O C_{A E}$ are the brake specific fuel oil consumptions (in $\mathrm{g} / \mathrm{kWh}$ ) of the main and auxiliaries engines at the $75 \%$ and $50 \%$ of their MCR points, respectively.

It must be also noted, that according to IMO [17], a baseline value of EEDI can be defined, based on regression analysis of data of several merchant ships. For the case of dry cargo bulk carriers, the following expression was proposed:

$$
E E D I_{b v}=1354 \cdot D W T^{-0.5117}
$$

\section{FINACIAL EVALUATION OF INVESTMENT IN MARITIME SECTOR}

The economic analysis of the alternative configurations for the ship propulsion plant was performed by calculating the annual machinery costs for each alternative, which is given by the following equation:

$$
A K=C A P E X+O P E X
$$

where $C A P E X$ is the capital expenditure and $O P E X$ is the operation expenditure.

The capital expenditure is given by the following equation:

$$
C A P E X=I C \cdot R \cdot \frac{(1+R)^{n}}{(1+R)^{n}-1}
$$

where $I C$ is the investment cost (i.e. machinery acquisition cost for each alternative), $R$ is the discount rate and $n$ is the lifetime of the investment.

The operation expenditure is given by the following equation:

$$
O P E X=A F C+A L O C+A M C
$$

where $A F C$ is the annual costs for fuel consumption (including heavy fuel oil-HFO and marine diesel oilMDO), $A L O C$ is the annual lubricating oil consumption costs and $A M C$ is the annual maintenance cost.

The discount rate (also referred as the cost of capital, opportunity cost, or weighted average cost of capital) is used in spreading the investment costs over the expected life of the investigated technology. Alternatively, it can be used for determining the present value of future benefits or costs. The discount rate is not a simple concept to understand nor is it easy to be precisely calculated. It can have a large impact on the results, and therefore, the selection of the proper value for the discount rate is important for accurately determining the capital expenditure. Increasing the discount rate value, lower present value of 
future costs/benefits is obtained. The discount rate should reflect the level of risk inherent in the cash flows being considered. Discount rate values, therefore, vary according to the risk (uncertainty) of the expected cash flows.

A minimum "risk free" discount rate values in the order of 4.0 to $4.5 \%$ for using in marginal abatement cost analysis of energy efficiency measures (including WHR) has been proposed in [19]. As it is commented in analysis presented in [19], the benefits and/or costs of energy efficiency measures are not necessarily "risk free", and therefore, a higher discount rate should be used to reflect the greater uncertainty in the expected benefits and/or costs. The typical approach for determining the appropriate discount rate value, which has to be used in discounting future cash flows to the present, is the weighted average cost of capital (WACC) for companies operating in the industry. The WACC for three companies was calculated in [19] and were found in the range from $9 \%$ to $12.5 \%$ having an average of $10.5 \%$. As a result, a $10 \%$ discount rate appears to be appropriate for the cost analysis. A maximum discount rate of $18 \%$ as high bound rate estimate was also proposed in [19]. This value was derived by taking into account the calculated average cost of equity for maritime firms, which was found to be $18 \%$.

When a new technology is introduced, there is usually a "learning curve" that over time yields cost reductions. This learning curve can occur due to several reasons. Companies may become more efficient in the production/delivery of the technology or achieve economies of scale as production volumes increase. Sometimes, it comes about through competition. Whatever the cause, it is widely established that the introduction of new technology usually sees the price fall over time. A $10 \%$ learning rate may be applied to the waste heat recovery technology.

Fuel consumption costs are included amongst the most intriguing costs of shipping. The increasing fuel price has significantly raised the voyage costs. The fuel consumption calculation is based on the typical route and operation profile. Handymax bulk carriers have typically longer range compared to the lower dead weight bulk carriers.

\section{APPLICATION CASES}

The propulsion plant installation of a typical handymax bulk carrier having deadweight of 55,000 $\mathrm{t}$ is examined. Such a ship requires a marine Diesel engine that produces about $8900 \mathrm{~kW}$ at MCR point [20]. 
At that power range, the following engine models can be selected as the ship propulsion engine: a) the two-stroke engine model 6S50-B8-TII from MAN Diesel [21] or 6RT-flex50 from Wärtsilä [22], b) the four-stroke engine model 8L48/60 from MAN Diesel [23] or 9L46 from Wärtsilä [24]. The main characteristics of the ship as well as the alternative propulsion plants are given in Table 1 .

The required engine data for modeling the WHR system include the exhaust gas mass flow rate, the temperature of the exhaust gas at the turbocharger turbine outlet and the air to fuel equivalence ratio of the exhaust gas. For the case of the heating the feed water using the engine air cooler, the temperature of the air exiting the turbocharger compressor is also required as input. All the required parameters are calculated for engine loads in the range from $50 \%$ to $100 \%$ of MCR, considering that the engines operate according to propeller law and ISO ambient conditions, using the data given in the engine project guides [21-24]. For the case of four-stroke engine, exhaust gas boiler by-pass of $20 \%$ was considered at MCR point. The engine fuel and air mass flow rates are derived from the exhaust gas mass flow rate and the air to fuel equivalence ratio.

For both engines the following tolerances were taken into account; for the exhaust gas temperature at turbocharger turbine outlet: $+15^{\circ} \mathrm{C}$; for the brake specific fuel consumption: $+3 \%$; for the exhaust gas mass flow rate: $-3 \%$. The values of the temperature and mass flow rate of the exhaust gas exiting the engine for both the examined engines as well as the exhaust gas thermal power, which are used in the WHR installation simulation cases presented below, are shown in Figure 2. For both cases, the exhaust gas thermal power is comparable in the engine load region from $50 \%$ to $85 \%$ of $\mathrm{MCR}$, whereas the exhaust gas thermal power of the four-stroke engine is $20 \%$ greater than the respective one of the twostroke engine at $100 \%$ engine load. However, the exhaust gas in the case of two-stroke engine is available at lower temperature values (from 90 to $150^{\circ} \mathrm{C}$ ) compared to the case of four-stroke engine, which it is expected to have negative impact on the steam cycle efficiency of the WHR system working with the two-stroke engine.

A set of results including the net produced electric power, the ship powerplant efficiency increase due to the production of the electric power from the WHR system, the steam cycle efficiency, the total powerplant efficiency and the minimum temperature difference at exhaust gas boiler pinch point for the cases of the ship propulsion installations with the two-stroke and the four-stroke engines, are presented in Figures 3 and 4, respectively. The following cases for the WHR system parameters were simulated: no 
heating of the feed water tank, heating of the feed water tank using saturated steam and heating the feed water tank using the engine air cooler. In all the simulated cases, the production of saturated steam for the ship heating services is assumed to be $500 \mathrm{~kg} / \mathrm{h}$. The used fuel is assumed to have a sulfur weight fraction $3 \%$, which limits the lower values of the temperature of the exhaust gas exiting the boiler to approximately $160^{\circ} \mathrm{C}$. The boiler drum pressure is considered to be 8.5 bar for the case of four-stroke engine, whereas it was set at 7 bar for the case of two-stroke engine in order to retain the temperature difference at pinch point above $10^{\circ} \mathrm{C}$ (due to the lower temperatures of the exhaust gas). The pressure of the condenser is taken as 0.065 bar. The water steam properties are calculated using the equations given in [25]. The average electric power, which is required for the examined ship, is estimated to $450 \mathrm{kWe}$ according to [1]. The net produced electric power for the two-stroke and four-stroke engine installations operating at load $85 \%$ of MCR, as function of the feed water temperature, are shown in Figure 5.

As it can be observed from Figure 3, the produced electric power for the case of the examined twostroke engine propulsion installation using WHR is not enough to cover the engine demands. The ship propulsion installation efficiency increase is in the region from 0.5 to $1.3 \%$ depending on the engine load. Due to the relatively low temperature of the engine exhaust gas, the produced superheated steam is also of low temperature, the pressure of the boiler drum is kept to 7 bar, and the obtained steam cycle efficiency is in the region from about 6 to $14 \%$. The total ship propulsion plant efficiency (considering that the produced saturated steam thermal power is entirely consumed in ship heating services) increases in the case of the WHR installation, reaching values in the region of 51 to $52 \%$. Due to the significant amount of electric power that is required to cover the ship demands, the installation of the considered WHR system is sought to be unbeneficial. In the case where a simpler, and thus less expensive, WHR system is installed for producing saturated steam for the ship heating services, the total ship propulsion plant efficiency also improves by 1.8 to $3 \%$ depending on the engine load.

For the case of the four-stroke engine ship propulsion installation, the higher temperature of the exhaust gas (approximately $80-150^{\circ} \mathrm{C}$ in comparison to the two-stroke engine case) results in higher temperature of the superheated steam and higher drum pressure $(8.5$ bar). Thus, the steam cycle efficiency is in the region of 12.5 to $18 \%$ and the produced net electric power reaches $450 \mathrm{kWe}$ at $100 \%$ load and over $250 \mathrm{kWe}$ at $50 \%$ load. The efficiency increase due to the electric power production is in the region from 2 to $3 \%$, thus resulting in a considerable improvement of the total efficiency of the ship 
propulsion installation, which reaches 48 to $49 \%$. The best results concerning the net produced electric power and WHR system efficiency increase are obtained using the option of heating the feed water to $120^{\circ} \mathrm{C}$ using the engine air cooler. However in this case, the exhaust gas boiler minimum temperature difference is only slightly higher than the limit $o 10^{\circ} \mathrm{C}$, indicating that a greater heat transfer area, and thus, increased volume exhaust gas boiler is required in such a case. From the above analysis, it is inferred that the installation of the examined WHR system is beneficial for the substantial improvement of the ship propulsion plant efficiency. The four-stroke engine propulsion installation with the WHR system reaches efficiencies comparable to the ones of the two-stroke engine propulsion system. However, the two-stroke engine with a WHR system for producing saturated steam to cover the ship heating services seems to be the best option for the examined ship propulsion installation, obtaining efficiency values from 49.5 to $51 \%$.

As it is shown in Figure 5, the heating of the feed water in higher temperature levels by using the saturated steam results in lower net electric power production, whereas the net produced electric power from the WHR installation increases in the case of heating the feed water by means of the engine air cooler. In the former case, the observed behavior is attributed to the greater amount of the saturated steam required for the feed water heating and therefore, less energy is available for the superheated steam production. However, in the latter case, the boiler economizer heat transfer rate is lower (for higher feed water temperatures), resulting in lower temperature difference at the boiler pinch point as also shown in Figures 3 and 4. Therefore, higher temperature of exhaust gas at boiler exit is required to retain the pinch point temperature greater than $10^{\circ} \mathrm{C}$. This, in turn, causes the reduction of the recoverable exhaust gas heat in the boiler, and thus the net produced electric power reaches an upper bound.

The attained Energy Efficiency Design Index was calculated using Equation 18 for the examined ship and for the various options for the ship propulsion plant installation (two-stroke engine with and without WHR, four-stroke engine with and without WHR), as well as for some recently build similar bulk carriers, the main characteristics of which are published in [26]. The derived results are presented in Figure 6. As it can be observed from Figure 6, the calculated EEDI for the case of four-stroke engine propulsion plant is 5.45, whereas the EEDI for the case of two-stroke engine propulsion plant is 5.11 . The baseline EEDI for the investigated bulk carrier is 5.08. It is also deduced that the WHR installation can reduce the EEDI by approximately $5.4 \%(\mathrm{EEDI}=5.16)$ in case of the four-stroke engine propulsion 
plant and $1.8 \%(E E D I=5.02)$ in case of the two-stroke engine installation. From EEDI point of view, a two-stroke engine solution is better compared to a four-stroke engine, since in the first case (two-stroke) the EEDI is slightly lower compared to the last case (four-stroke), even when WHR system is used in the last solution. In addition, it can be concluded that only a two-stroke engine solution with WHR can result in EEDI below the baseline. However, in such a case, owing to the relatively low electric power production using the WHR installation of single steam pressure, more complicated WHR installations are required (e.g. with two different steam pressure levels and additional heat recovery from the engine air cooler and/or engine jacket cooling water).

As it is deduced from the above analysis, the installation of a WHR system with turbogenerator for producing electric power cannot be considered as a viable option in the case of the two-stroke engine propulsion plant of the examined bulk carrier. As a result, the following cases will be evaluated on an economical basis: a) Two-Stroke Engine propulsion configuration without WHR, b) Four-Stroke Engine propulsion configuration without WHR and c) Four-Stroke Engine Propulsion configuration with WHR.

The examined bulk carrier is assumed to transport iron ore from Brazil (Rio de Janeiro) to Netherlands (Rotterdam). The distance of this route is 5243 nautical miles and it takes approximately 15 sea days at 14.8 knots in order to complete this route. In addition, the ship unloading using the onboard grabs $(1000 \mathrm{t} / \mathrm{h})$ is estimated to last about $48 \mathrm{~h}$, whereas the ship loading using the port loaders $(3500 \mathrm{t} / \mathrm{h})$ is estimated to last about $12 \mathrm{~h}$.

The operation profile of the bulk carrier is dominated by her sailing time at service speed and therefore, the fuel cost of bulk carrier is mainly dependent on the heavy fuel oil consumption of the main engine. The typical electric power demand at sea for the examined Handymax bulker $(450 \mathrm{~kW})$ is assumed to be covered by using the one auxiliary Diesel generator. The ship electric demand at port is produced by the ship auxiliary Diesel engines.

The detailed ship operation profile and the propulsion plant operational characteristics for the examined three alternative options are briefly presented in Table 2. Based on figures presented in recent publications $[19,27-28]$, the machinery costs estimations for each one of the three ship propulsion plant alternatives are given in Table 3 .

The annual machinery costs were calculated for each propulsion plant alterative, considering eleven roundtrips per year, HFO price $600 € / \mathrm{t}$, MDO price $840 € / \mathrm{t}$ and a discount rate of $10 \%$. The results are 
presented in Figure 7. As can be observed in Figure 7, there are significant savings when a WHR system is added in a baseline four-stroke engine propulsion plant. In detail, the savings found to be $440,500 € /$ year, which give to the additional investment of the WHR system a payback period of around 2.4 years (Figure 8) and an Internal Rate of Return (IRR) equal to $48.7 \%$, justifying completely the installation of such a system. It must be noticed that the optimum solution remains the two-stroke propulsion plant with around $180,000 €$ annual savings compared with the four-stroke propulsion plant with WHR system. Even taking into consideration that the estimated price of the WHR will probably reduce in the following years about $10 \%$ (learning rate) the result is not changing significantly, and the two-stroke solution remains the most cost effective solution with annual savings of around $170,000 €$. This saving difference between the two most competitive solutions, i.e. four-stroke engine with WHR and two-stroke engine, is eliminated only, when the acquisition cost of the two-stroke engine will increase $31 \%$, which initially seems not so possible to occur.

In order to further investigate the sensitivity of the results from the assumed financial and operational input parameters, several calculations were performed for different discount rates $(4 \%, 10 \%$ and $18 \%)$, fuel prices (from $200 € / t$ to $600 € / t$ ) and plant utilizations (8 roundtrips and 11 roundtrips) and the results are presented in Tables 4 and 5. It is evident that, the increase of fuel price rises the annual operating cost for all alternative solutions. On the other hand, low discount rates reduce the cost of capital and make the additional investment of a WHR system more attractive. As a rule of thumb, the WHR system is more cost-effective as the price of fuel increases and the discount rate (cost of capital) decreases, and vice versa. This also explains the extremely high payback periods (higher than the investment lifetime, 20 years here) observed for high discount rates $(18 \%)$ and low fuel prices $(200-300 € / t)$, which make the procurement and installation of a WHR system a non-feasible solution.

Although the solution of a two-stroke engine propulsion plant appears to be the most cost-effective solution for all combinations of discount rates, fuel prices and ship utilization rates (number of roundtrips), it should be highlighted the fact that in the cases of high cost of capital, a two-stroke engine price increase in the range of $22 \%-25 \%$ can make the four-stroke engine with WHR system significantly competitive (equal) with the two-stroke. In addition, and taking into consideration that nowadays, a fourstroke HFO Diesel engine can be converted to Dual-Fuel Engine capable of burning 99\% LNG as a primary fuel, with significantly lower emission footprint and in some cases lower operational costs, 
compared to a two-stroke HFO Diesel engine, it can be concluded that further investigation is needed, if LNG is to be examined as an alternative fuel offering better efficiency, lower $\mathrm{CO}_{2}$ and $\mathrm{NOx}$ footprint and lower operational costs.

\section{CONCLUSIONS}

The performance of the WHR system of single steam pressure type comprising an external heat exchanger for heating the feed water entering into the boiler drum was investigated for the cases of a handymax class bulk carrier propulsion plant installation with a two-stroke engine and a four-stroke engine. The options of heating the feed water using saturated steam or alternatively by recovering heat from the engine air cooler were also considered. In addition, the ship EEDI values, which represent the ship $\mathrm{CO}_{2}$ efficiency, were calculated for the examined cases of the ship propulsion plant installation.

The main findings derived from this work are summarized as follows.

The two-stroke engine in combination with a WHR system for producing saturated steam is the best option for the propulsion plant installation of the examined ship. However, in order to obtain an EEDI below the corresponding baseline value, a two-stroke engine combined with a more complex (and as a result more effective) WHR system (e.g. with two steam pressure levels and recovery of heat for the engine air cooler and jacket cooling water) has to be used.

In the case of four-stroke engine propulsion installation, the utilization of the WHR system is necessary for considerably increasing the installation efficiency, which however remains lower than the one of the two-stroke engine installation.

The heating of feed water using the engine air cooler improves the WHR system efficiency, but an upper bound exists at temperatures about 100 to $120^{\circ} \mathrm{C}$. On the other hand, the heating of the feed water by means of saturated steam slightly decreases the WHR system efficiency.

From economical point of view, the solution of a two-stroke engine propulsion plant appears to be the most cost-effective scheme for all investigated combinations of discount rates, fuel prices and ship utilization rates (number of roundtrips). It was also observed that a four-stroke engine propulsion installation with WHR could reach the same cost-effectiveness, only when the competing two-stroke engine propulsion plant exhibits at least a $22 \%$ price increase in the best case scenario. 


\section{REFERENCES}

1. SNAME. 1990. Marine Diesel Power Plant Practices. T\&R Bulletin 3-49.

2. MAN Diesel \& Turbo. 2009. Soot Deposits and Fires in Exhaust Gas Boilers. Publ. No. 55100065-00. Copenhagen, Denmark.

3. Ioannidis, J. 1984. Waste Heat Recovery from Diesel Engines. Proc of IMAM 1984 conference. Vol. II, pp. 437-449, Athens, Greece.

4. Dzida, M. 2009. On the possible increasing of efficiency of ship power plant with the system combined of marine diesel engine, gas turbine and steam turbine, at the main engine-steam turbine mode of cooperation. Polish Maritime Research, 1(59), 16, pp. 47-52.

5. Schmid, H. 2004. Less emissions through waste heat recovery. Green Ship Technology Conference, London, 28-29 April 2004, London, UK.

6. MAN Diesel \& Turbo. 2005. Thermo Efficiency System (TES) for Reduction of Fuel Consumption and CO2 Emission. Publ. No.: P3339161, Copenhagen, Denmark.

7. Rupp M. 2007. Green ships on the high seas. ABB Review 4/2007, pp. 58-61..

8. MAN Diesel \& Turbo. 2008. Exhaust Gas Emission Control Today and Tomorrow-Application on MAN B\&W Two-stroke Marine Diesel Engines. Publ. No. 5510-0060-00, Copenhagen, Denmark.

9. Dzida, M. 2009. On the possible increasing of efficiency of ship power plant with the system combined of marine diesel engine, gas turbine and steam turbine in case of main engine cooperation with the gas turbine fed in parallel and the steam turbine. Polish Maritime Research, 2(60), 16, pp. 40-44.

10. Valdes, M., and Rapun, J.L. 2001. Optimization of heat recovery steam generators for combined cycle gas turbine power plants, Applied Thermal Engineering 21, pp. 1149-1159.

11. Tien, W.-K., Yeh, R.-H., and Hong J.-M. 2007. Theoretical analysis of cogeneration system for ships. Energy Conversion and Management, 48, pp. 1965-1974. 
12. Aklilu, B.T., and Gilani, S.I. 2010. Mathematical modeling and simulation of a cogeneration plant. Applied Thermal Engineering, 30, pp. 2545-2554.

13. Dimopoulos, G.G., and Kakalis, N.M.P., 2010, An integrated modeling framework for the design operation and control of marine energy systems, Proc. CIMAC Congress 2010, Paper No. 154. Bergen, Norway.

14. Dimopoulos G.G., Georgopoulou, Ch.A., and Kakalis, N.M.P. 2011. Modelling and optimisation of an integrated marine combined cycle system. In Proceedings of ECOS 2011 Conference, Novi Sad, Serbia, July 4-7 2011, pp. 1283-1298.

15. Grimmelius, H, Boonen, E.-J., Nicolai, H., and Stapersma, D. 2010. The integration of mean value first principle diesel engine models in dynamic waste heat and cooling load analysis. Proc. CIMAC Congress 2010, Paper No. 280. Bergen, Norway.

16. IMO. 2009. Interim Guidelines on the Method of Calculation of the Energy Efficiency Design Index for New Ships. MEPC.1/Circ.681.

17. IMO. 2009. Recalculation of energy efficiency design index baselines for cargo ships. GHG-WG $2 / 2 / 7$.

18. Ganapathy, V. 2003. Industrial Boilers and Heat Recovery Steam Generators-Design, Applications, and Calculations. Marcel Dekker Inc.

19. Russel, B., and Amand, D. 2011. Marginal Abatement Costs and Cost Effectiveness of Energy Efficiency Measures. SNAME T\&R Program. Panel AHP 20: Greenhouse Gases \& Economics, March 2011.

20. MAN Diesel \& Turbo. 2010. Propulsion trends in bulk carriers. Publ. No. 5510-0007-02, Copenhagen, Denmark.

21. MAN Diesel \& Turbo. 2010. MAN B\&W S50ME-B8-TII Project Guide. 7020-0103-00, Copenhagen, Denmark.

22. Wärtsilä. 2011. Ship Power Product Catalogue, Finland.

23. MAN Diesel \& Turbo. 2009. Project Guide for Marine Plants, Diesel Engine L+V48/60CR. Augsburg, Germany.

24. Wärtsilä. 2007. Wärtsila 46 project guide. 3/2007, Finland.

25. Wagner, W., and Kretzschmar H.-J. 2008. International Steam Tables. Springer-Verlag. 
26. Lingwood, J (ed). 2005. Significant Ships of 2005. RINA. U.K.

27. Bui, Y. 2011. Machinery Concepts and LNG for meeting IMO Tier III rules. Wärtsilä Technical Journal: Marine/InDetail, 01/2011, pp. 31-38.

28. MAN Diesel and Turbo. 2011. MAN Diesel and Turbo Technology Boosts Efficiency-WHR and TCS-PTG improve efficiency on large engines. Ref. No.: 6510-0238, 6/2011, Copenhagen, Denmark. 


\section{APPENDIX}

\section{Notation}

AFC annual costs for fuel consumption ( $€$ )

AK annual machinery cost $(€)$

ALOC annual lubricating oil consumption costs $(€)$

AMC annual maintenance cost $(€)$

$\mathrm{c}_{\mathrm{p}} \quad$ specific heat at constant pressure $(\mathrm{J} / \mathrm{kg} / \mathrm{K})$

$\mathrm{C}_{\mathrm{F}} \quad$ conversion factor $\left(\mathrm{g} \mathrm{CO}_{2} / \mathrm{g}\right.$ fuel $)$

CAPEX capital expenditure $(€)$

DWT deadweight $(t)$

EEDI Energy Efficiency Design Index $\left(\mathrm{g} \mathrm{CO}_{2} / \mathrm{t} / \mathrm{NM}\right)$

f $\quad$ correction factors (-)

h $\quad$ specific enthalpy $(\mathrm{J} / \mathrm{kg})$

$\mathrm{H}_{\mathrm{L}} \quad$ lower heating value $(\mathrm{J} / \mathrm{kg})$

IC investment $\operatorname{cost}(€)$

IRR internal rate of return (\%)

$\dot{m} \quad$ mass flow rate $(\mathrm{kg} / \mathrm{s})$

$\mathrm{n} \quad$ lifetime of investment (years)

OPEX operation expenditure $(€)$

P power $(\mathrm{W})$

$\dot{Q} \quad$ heat transfer rate (W)

$\mathrm{R} \quad$ discount rate $(-, \%)$

SFOC brake specific fuel consumption $(\mathrm{g} / \mathrm{kWh})$

SLOC brake specific lubricating oil consumption $(\mathrm{g} / \mathrm{kWh})$

$\mathrm{T} \quad$ temperature $(\mathrm{K})$

$\mathrm{V}_{\text {ref }} \quad$ reference ship speed $(\mathrm{kn})$

$\eta \quad$ efficiency, effectiveness (-)

$\Delta \mathrm{p} \quad$ pressure drop, pressure increase $(\mathrm{Pa})$ 
$\Delta \mathrm{T} \quad$ temperature difference $(\mathrm{K})$

$\Delta \eta \quad$ efficiency increase (-)

$\rho \quad$ density $\left(\mathrm{kg} / \mathrm{m}^{3}\right)$

\section{Subscripts}

$\begin{array}{ll}\text { a } & \text { air } \\ \text { ac } & \text { air cooler } \\ \text { AE } & \text { auxiliary engine } \\ \text { b } & \text { boiler } \\ \text { bv } & \text { baseline value } \\ \text { c } & \text { condensate water } \\ \text { cw } & \text { circulating water } \\ \text { d } & \text { drum } \\ \text { ec } & \text { economizer } \\ \text { el } & \text { electric } \\ \text { ev } & \text { evaporator } \\ \text { f } & \text { fuel } \\ \text { fw } & \text { feed water } \\ \text { g } & \text { exhaust gas } \\ \text { G } & \text { generator } \\ \text { pd } & \text { pump downstream } \\ \text { hs } & \text { heating service } \\ \text { HT } & \text { high temperature } \\ \text { i } & \text { inlet } \\ \text { is } & \text { isentropic } \\ \text { ME } & \text { mechanical } \\ \text { main engine } \\ \text { outlet } \\ \text { poring }\end{array}$




$\begin{array}{ll}\text { pu } & \text { pump upstream } \\ \text { s } & \text { saturated steam } \\ \text { sh } & \text { superheater, superheated steam } \\ \text { ST } & \text { steam turbine } \\ \text { SW } & \text { sea water } \\ \text { TG } & \text { turbogenerator } \\ \text { W } & \text { saturated water }\end{array}$

\section{Abbreviations}

$\begin{array}{ll}\text { AE } & \text { auxiliary engine(s) } \\ \mathrm{CO}_{2} & \text { carbon dioxide } \\ \text { EIAPP } & \text { Engine International Air Pollution Prevention } \\ \text { HFO } & \text { heavy fuel oil } \\ \text { IMO } & \text { International Maritime Organization } \\ \text { LNG } & \text { liquefied natural gas } \\ \text { MCR } & \text { maximum continuous rating } \\ \text { MDO } & \text { marine diesel oil } \\ \text { ME } & \text { main engine(s) } \\ \text { NOx } & \text { nitrogen oxides } \\ \text { WACC } \quad \text { weighted average cost of capital } & \\ \text { WHR } & \text { waste heat recovery }\end{array}$




\section{LIST OF FIGURE CAPTIONS}

Figure 1 Waste heat recovery installation of single steam pressure for production of saturated steam and electric power

Figure 2 Engine exhaust gas parameters as function of engine load

Figure 3 WHR system parameters for the examined two-stroke engine propulsion plant

Figure 4 WHR system parameters for the examined four-stroke marine engine propulsion plant

Figure 5 Effect of feed water temperature on produced electric power for the two-stroke and four-stroke engines installations

Figure 6 EEDI for the several alternative propulsion plants of the test ship and some recently build similar ships

Figure 7 Annual machinery costs for the investigated alternative propulsion plants

Figure 8 Four-stroke engine propulsion plant with WHR - Cumulative operating savings

\section{LIST OF TABLE CAPTIONS}

Table 1 Main parameters of ship and examined engines

Table 2 Propulsion plant operational characteristics for the three investigated configurations

Table 3 Specific Machinery Costs

Table 4 Annual machinery related costs assuming 8 roundtrips per year

Table 5 Annual machinery related costs assuming 11 roundtrips per year 


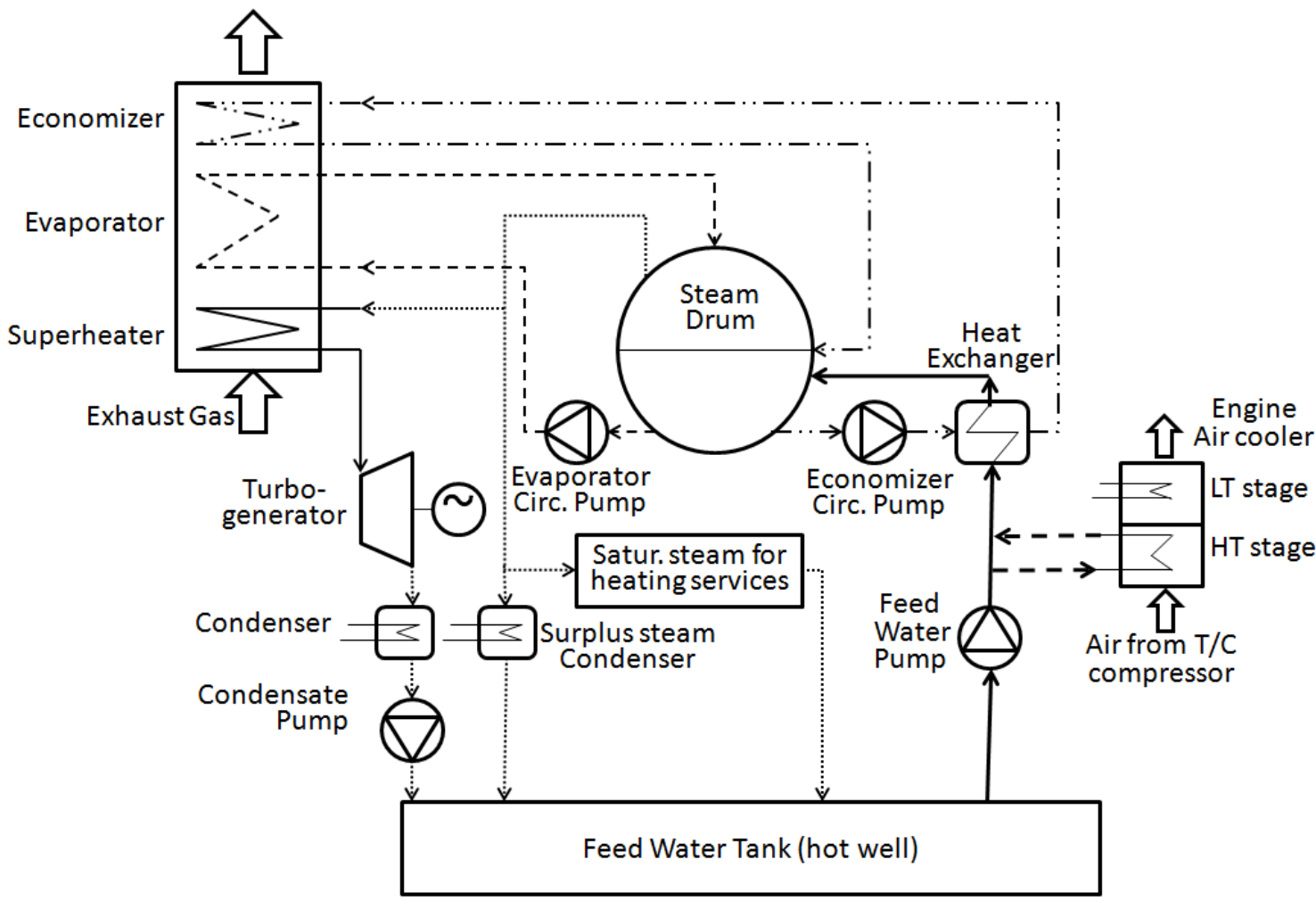

Figure 1 Waste heat recovery installation of single steam pressure for production of saturated steam and electric power
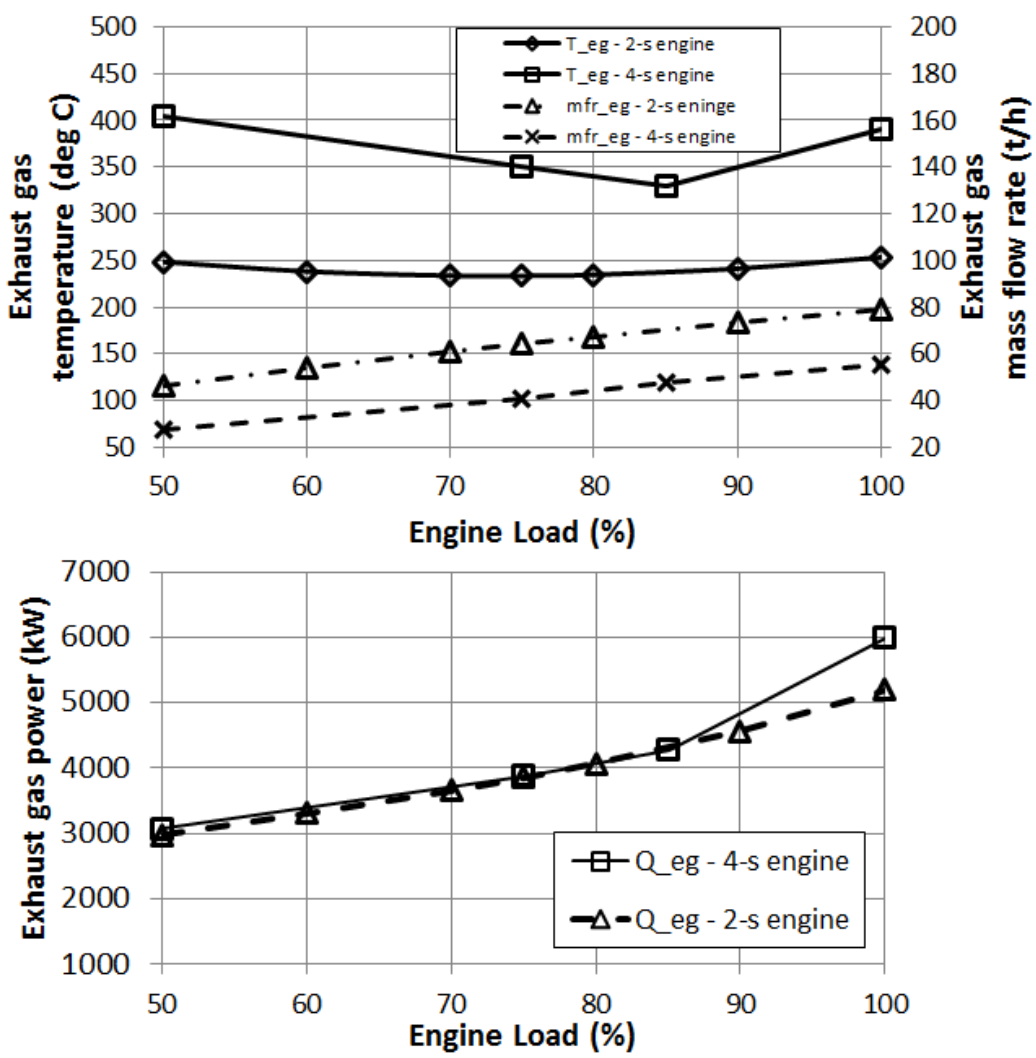

Figure 2 Engine exhaust gas parameters as function of engine load 

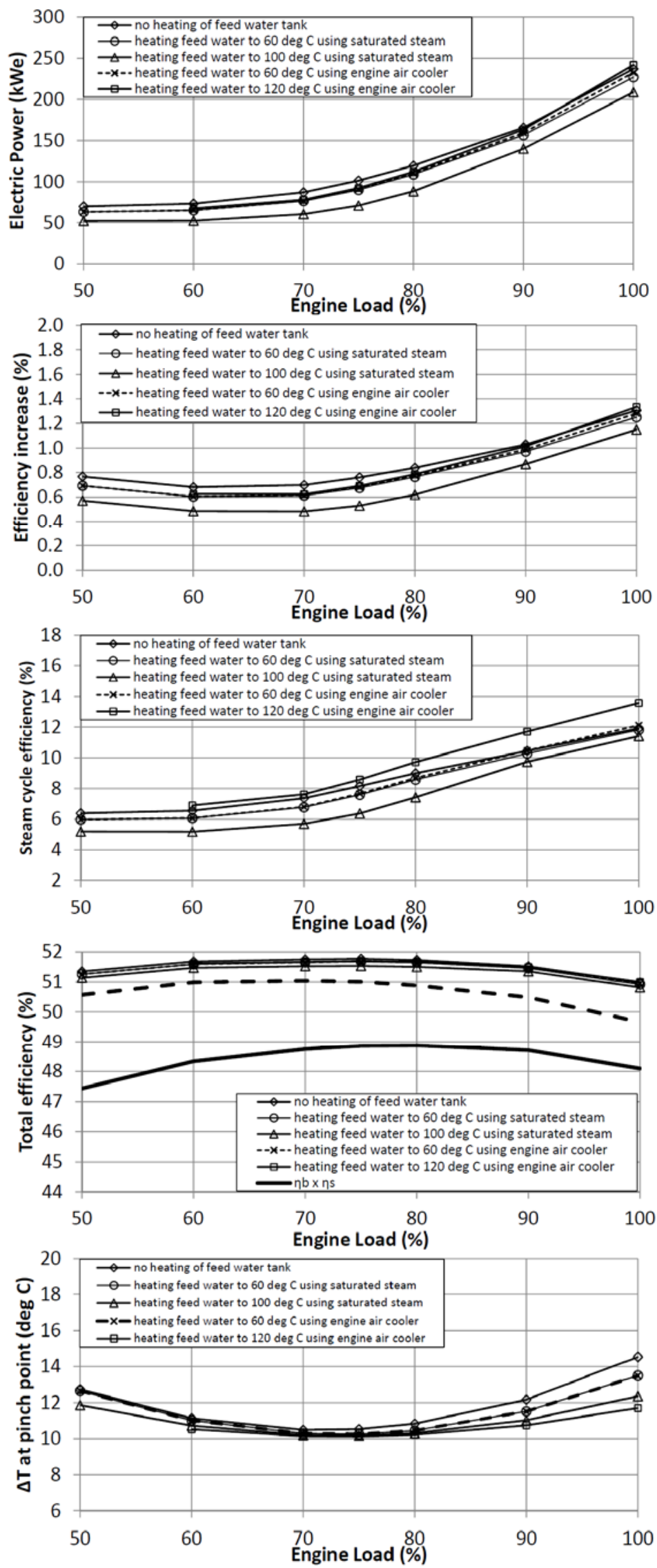

Figure 3 WHR system parameters for the examined two-stroke engine propulsion plant 

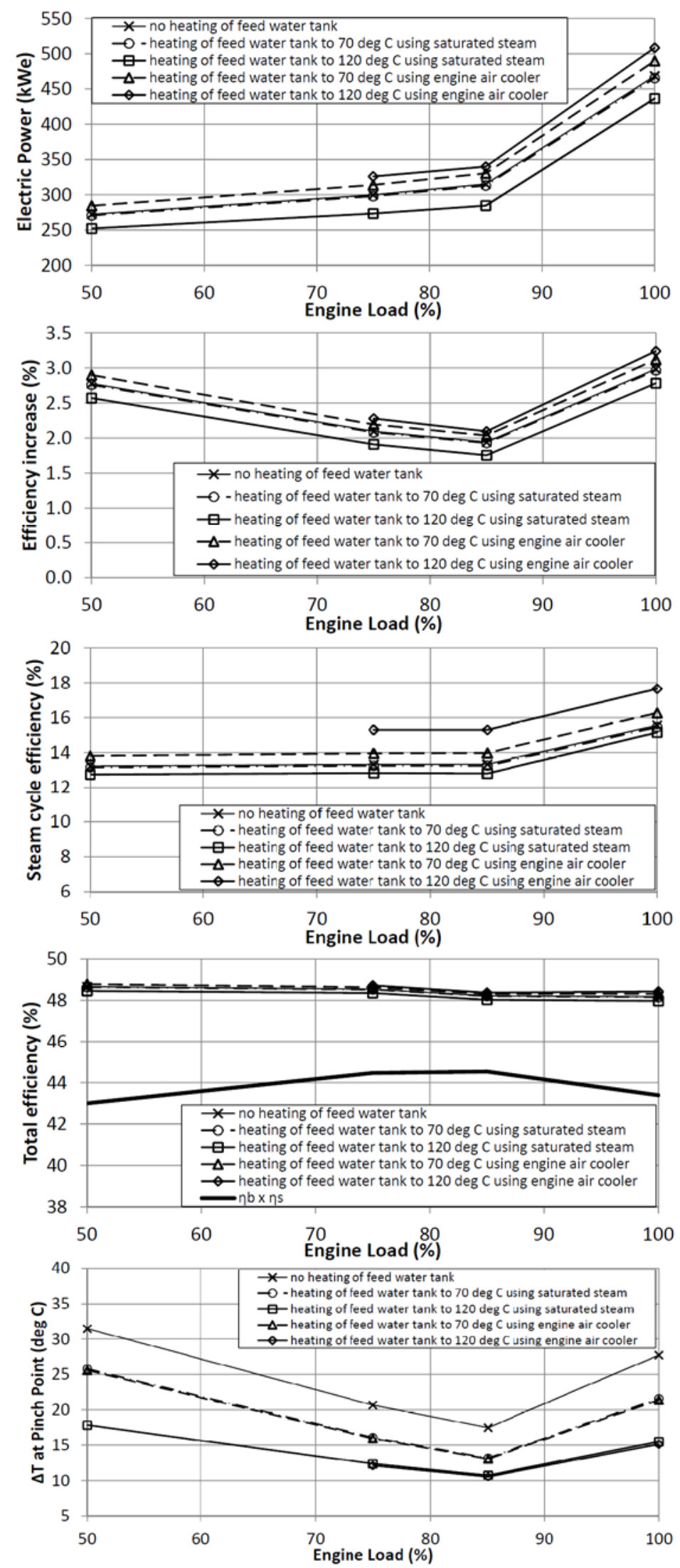

Figure 4 WHR system parameters for the examined four-stroke marine engine propulsion plant 


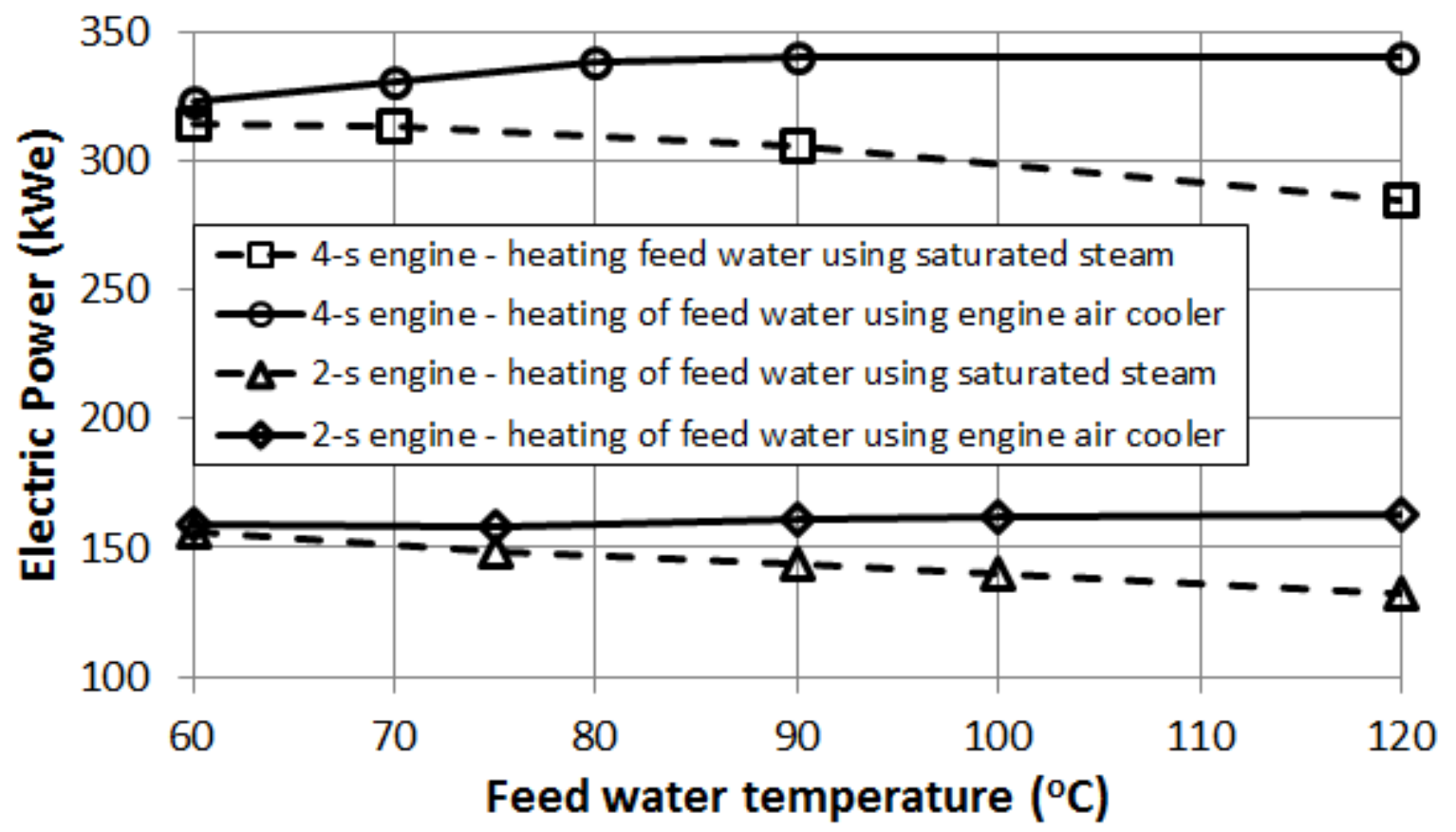

Figure 5 Effect of feed water temperature on produced electric power for the two-stroke and four-stroke engines installations

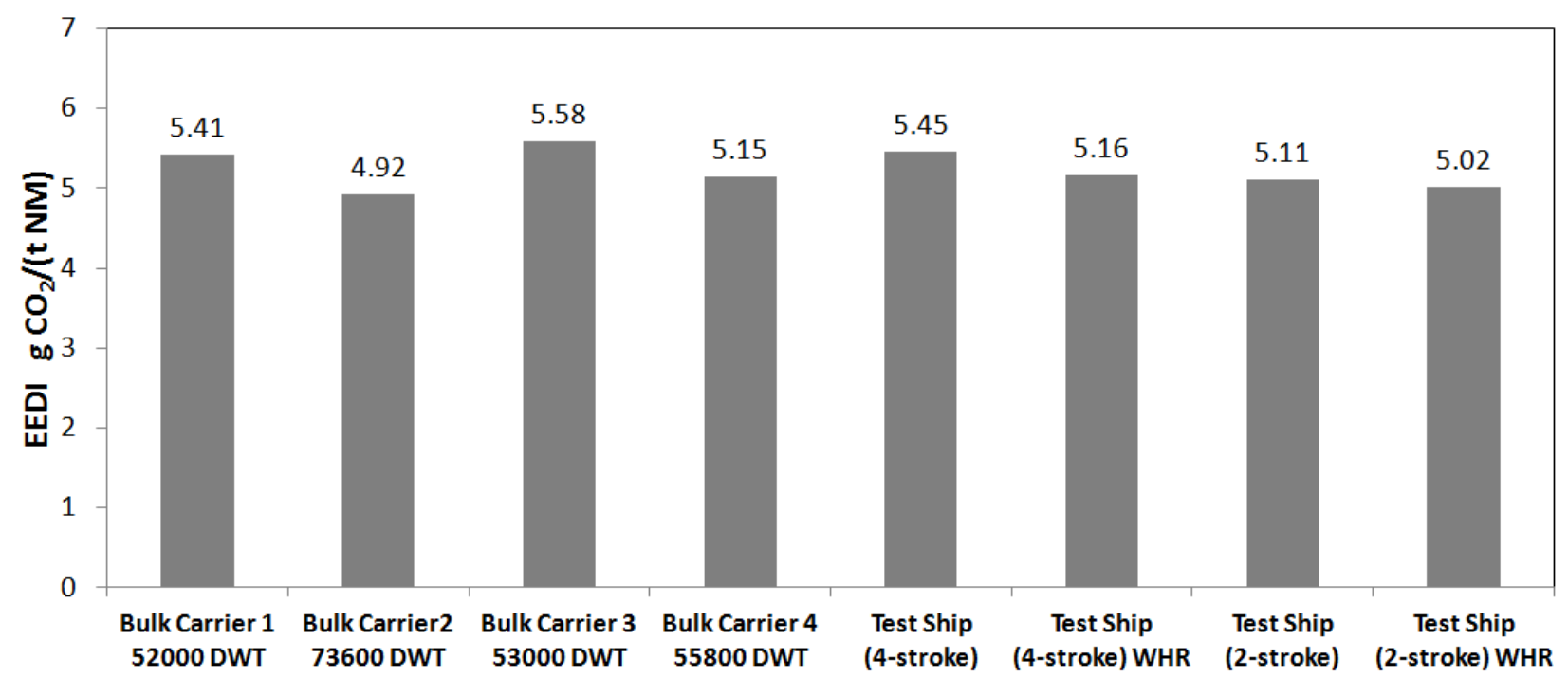

Figure 6 EEDI for the several alternative propulsion plants of the test ship and some recently build similar ships 


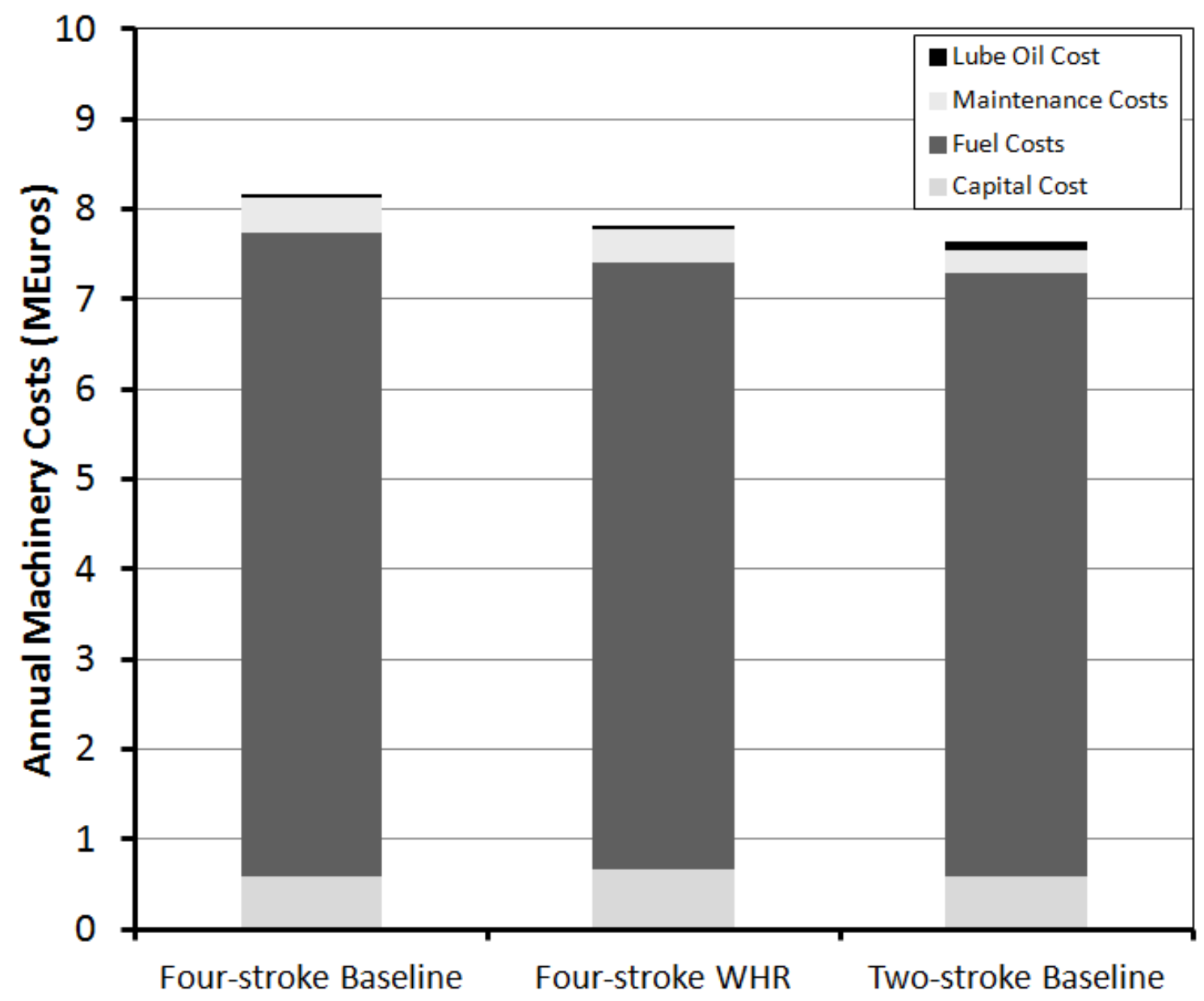

Figure 7 Annual machinery costs for the investigated alternative propulsion plants

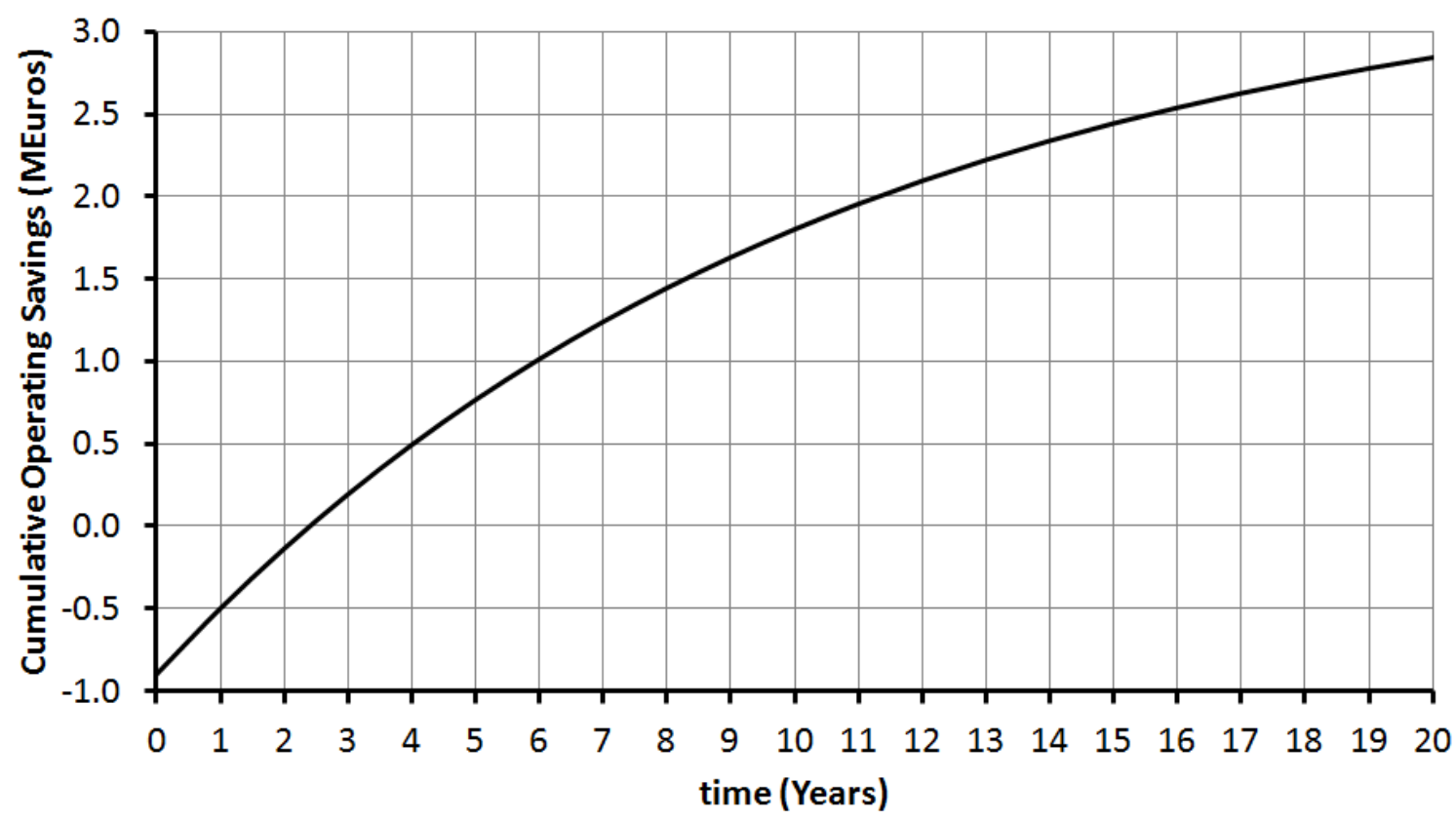

Figure 8 Four-stroke engine propulsion plant with WHR - Cumulative operating savings 
Table 1 Main parameters of ship and examined engines

\begin{tabular}{llc}
\hline Ship parameters - typical values \\
Type & bulk carrier (Handymax) \\
Size (at scantling draught) [mt] & 55,000 \\
Length between perpendiculars & {$[\mathrm{m}]$} & 185 \\
Breadth [m] & \multicolumn{2}{c}{32.0} \\
Draught (scantling) [m] & 12.5 \\
Vessel speed [kn] & 14.5 \\
\hline Engine parameters - typical values & four-stroke \\
Engine type & two-stroke \\
Bore [mm] & 500 & 460 \\
Stroke [mm] & 2000 & 580 \\
Brake power at MCR [kW] & 8815 & 8775 \\
Engine speed at MCR [rpm] & 122 & 500 \\
BSFC at MCR [g/kWh] & $171 \pm 5 \%$ & $183 \pm 5 \%$ \\
\hline
\end{tabular}


Table 2 Propulsion plant operational characteristics for the three investigated configurations

\begin{tabular}{|c|c|c|c|c|}
\hline & Port & Maneuvering & $8 \mathrm{kn}$ & $14.8 \mathrm{kn}$ \\
\hline Running Hours per Roundtrip & 60 & 2 & 10 & 720 \\
\hline \multicolumn{5}{|l|}{ Four-stroke Engine Propulsion Plant } \\
\hline Main Engine (ME) Load [\%] & 0 & 11.5 & 13.9 & 85.1 \\
\hline Auxiliary Engines (AE) Load [\%] & 50 & 65 & 65 & 65 \\
\hline Number of Auxiliary Engines Running & 2 & 1 & 1 & 1 \\
\hline ME SFOC $[\mathrm{g} / \mathrm{kWh}]$ & 0 & 218.6 & 216.0 & 183.8 \\
\hline AE SFOC $[\mathrm{g} / \mathrm{kWh}]$ & 201.9 & 197.3 & 197.3 & 197.3 \\
\hline ME SLOC [g/kWh] & 0.5 & 0.5 & 0.5 & 0.5 \\
\hline AE SLOC $[\mathrm{g} / \mathrm{kWh}]$ & 0.5 & 0.5 & 0.5 & 0.5 \\
\hline HFO Boiler Steam Production $[\mathrm{kg} / \mathrm{h}]$ & 500 & 500 & 500 & 500 \\
\hline HFO Boiler Efficiency [\%] & 90 & 90 & 90 & 90 \\
\hline \multicolumn{5}{|c|}{ Four-stroke Engine Propulsion Plant with WHR } \\
\hline Main Engine (M.E.) Load [\%] & 0 & 11.5 & 13.9 & 85.1 \\
\hline Auxiliary Engines (AE) Load [\%] & 50 & 65 & 65 & 18 \\
\hline Number of Auxiliary Engines Running & 2 & 1 & 1 & 1 \\
\hline ME SFOC $[\mathrm{g} / \mathrm{kWh}]$ & 0 & 218.6 & 216.0 & 183.8 \\
\hline AE SFOC $[\mathrm{g} / \mathrm{kWh}]$ & 201.9 & 197.3 & 197.3 & 217.5 \\
\hline ME SLOC $[\mathrm{g} / \mathrm{kWh}]$ & 0.5 & 0.5 & 0.5 & 0.5 \\
\hline AE SLOC $[\mathrm{g} / \mathrm{kWh}]$ & 0.5 & 0.5 & 0.5 & 0.5 \\
\hline HFO Boiler Steam Production $[\mathrm{kg} / \mathrm{h}]$ & 500 & 500 & 500 & 0 \\
\hline HFO Boiler Efficiency [\%] & 90 & 90 & 90 & 90 \\
\hline WHR Steam Production for Use $[\mathrm{kg} / \mathrm{h}]$ & - & - & - & 500 \\
\hline WHR Produced electrical energy [kWe] & - & - & - & 340 \\
\hline \multicolumn{5}{|l|}{ Two-stroke Engine Propulsion Plant } \\
\hline Main Engine (ME) Load [\%] & 0 & 11.5 & 13.9 & 84.7 \\
\hline Auxiliary Engines (AE) Load [\%] & 50 & 65 & 65 & 65 \\
\hline Number of Auxiliary Engines Running & 2 & 1 & 1 & 1 \\
\hline ME SFOC $[\mathrm{g} / \mathrm{kWh}]$ & 0 & 195.1 & 193.3 & 170.6 \\
\hline AE SFOC $[\mathrm{g} / \mathrm{kWh}]$ & 201.9 & 197.3 & 197.3 & 217.5 \\
\hline ME SLOC [g/kWh] & 1.0 & 1.0 & 1.0 & 1.0 \\
\hline AE SLOC $[\mathrm{g} / \mathrm{kWh}]$ & 0.5 & 0.5 & 0.5 & 0.5 \\
\hline HFO Boiler Steam Production $[\mathrm{kg} / \mathrm{h}]$ & 500 & 500 & 500 & 500 \\
\hline HFO Boiler Efficiency [\%] & 90 & 90 & 90 & 90 \\
\hline
\end{tabular}


Table 3 Specific Machinery Costs

Specific Machinery Cost in $€$ per installed kW

Four-stroke Four-stroke WHR Two-stroke

Main Engine [€/ME kW]

259

259

275

Propulsion Line [€/ME kW]

220

220

200

Auxiliary Engines [ $€ / \mathrm{AE} \mathrm{kW]}$

278

278

278

WHR or simple HFO Boiler [€/ME kW]

19.3

103

19.3 
Table 4 Annual machinery related costs assuming 8 roundtrips per year

Annual Costs (8 Roundtrips per year)

\begin{tabular}{|c|c|c|c|c|c|c|c|c|}
\hline $\begin{array}{c}\text { MDO } \\
\text { Price } \\
{[€ / t]}\end{array}$ & $\begin{array}{c}\text { HFO } \\
\text { Price } \\
{[€ / t]}\end{array}$ & $\begin{array}{c}\text { Four-stroke } \\
\text { Baseline }\end{array}$ & $\begin{array}{c}\text { Four-stroke } \\
\text { WHR }\end{array}$ & $\begin{array}{c}\text { Two-stroke } \\
\text { Baseline }\end{array}$ & $\begin{array}{c}\text { Pay-back } \\
\text { time } \\
\text { (years) }\end{array}$ & IRR & Selection & $\begin{array}{l}\text { Two-stroke } \\
\text { price scale } \\
\text { for } \\
\text { equivalence }\end{array}$ \\
\hline \multicolumn{9}{|c|}{ RATE 4\% } \\
\hline 280 & 200 & $2,411,756 €$ & $2,350,185 €$ & $2,247,426 €$ & 10 & $11.30 \%$ & $2-\mathrm{s}$ & 1.28 \\
\hline 420 & 300 & $3,279,475 €$ & $3,166,697 €$ & $3,059,046 €$ & 6 & $17.70 \%$ & $2-\mathrm{s}$ & 1.30 \\
\hline 560 & 400 & $4,147,195 €$ & $3,983,210 €$ & $3,870,666 €$ & 5 & $23.80 \%$ & $2-\mathrm{s}$ & 1.31 \\
\hline 700 & 500 & $5,014,914 €$ & $4,799,722 €$ & $4,682,286 €$ & 4 & $29.60 \%$ & $2-\mathrm{s}$ & 1.32 \\
\hline 840 & 600 & $5,882,633 €$ & $5,616,234 €$ & $5,493,906 €$ & 3 & $35.40 \%$ & $2-\mathrm{s}$ & 1.34 \\
\hline \multicolumn{9}{|c|}{ RATE 10\% } \\
\hline 280 & 200 & $2,629,992 €$ & $2,600,620 €$ & $2,464,955 €$ & 16 & $11.28 \%$ & $2-\mathrm{s}$ & 1.23 \\
\hline 420 & 300 & $3,497,711 €$ & $3,417,132 €$ & $3,276,575 €$ & 8 & $17.70 \%$ & $2-\mathrm{s}$ & 1.24 \\
\hline 560 & 400 & $4,365,430 €$ & $4,233,644 €$ & $4,088,195 €$ & 6 & $23.80 \%$ & $2-\mathrm{s}$ & 1.25 \\
\hline 700 & 500 & $5,233,149 €$ & $5,050,156 €$ & $4,899,815 €$ & 5 & $29.60 \%$ & $2-\mathrm{s}$ & 1.26 \\
\hline 840 & 600 & $6,100,869 €$ & $5,866,668 €$ & $5,711,435 €$ & 4 & $35.40 \%$ & $2-\mathrm{s}$ & 1.27 \\
\hline \multicolumn{9}{|c|}{ RATE $18 \%$} \\
\hline 280 & 200 & $2,974,970 €$ & $2,996,496 €$ & $2,808,816 €$ & $\mathrm{~N} / \mathrm{A}$ & $11.28 \%$ & $2-\mathrm{s}$ & 1.20 \\
\hline 420 & 300 & $3,842,689 €$ & $3,813,008 €$ & $3,620,436 €$ & $\mathrm{~N} / \mathrm{A}$ & $17.70 \%$ & $2-\mathrm{s}$ & 1.21 \\
\hline 560 & 400 & $4,710,408 €$ & $4,629,520 €$ & $4,432,056 €$ & 9 & $23.80 \%$ & $2-\mathrm{s}$ & 1.21 \\
\hline 700 & 500 & $5,578,127 €$ & $5,446,032 €$ & $5,243,676 €$ & 6 & $29.60 \%$ & $2-\mathrm{s}$ & 1.22 \\
\hline 840 & 600 & $6,445,847 €$ & $6,262,545 €$ & $6,055,296 €$ & 4 & $35.40 \%$ & $2-\mathrm{s}$ & 1.22 \\
\hline
\end{tabular}


Table 5 Annual machinery related costs assuming 11 roundtrips per year

\section{Annual Costs (11 Roundtrips per year)}

\begin{tabular}{|c|c|c|c|c|c|c|c|c|}
\hline $\begin{array}{l}\text { MDO } \\
\text { Price } \\
{[€ / t]}\end{array}$ & $\begin{array}{c}\text { HFO } \\
\text { Price } \\
{[€ / t]}\end{array}$ & $\begin{array}{c}\text { Four-stroke } \\
\text { Baseline }\end{array}$ & $\begin{array}{c}\text { Four-stroke } \\
\text { WHR }\end{array}$ & $\begin{array}{c}\text { Two-stroke } \\
\text { Baseline }\end{array}$ & $\begin{array}{c}\text { Pay-back } \\
\text { time } \\
\text { (years) }\end{array}$ & IRR & Selection & $\begin{array}{l}\text { Two-stroke } \\
\text { price scale } \\
\text { for } \\
\text { equivalence }\end{array}$ \\
\hline \multicolumn{9}{|c|}{ RATE 4\% } \\
\hline 280 & 200 & $3,178,924 €$ & $3,074,016 €$ & $2,953,414 €$ & 7 & $16.80 \%$ & $2-\mathrm{s}$ & 1.33 \\
\hline 420 & 300 & $4,372,038 €$ & $4,196,720 €$ & $4,069,392 €$ & 5 & $25.10 \%$ & $2-\mathrm{s}$ & 1.35 \\
\hline 560 & 400 & $5,565,152 €$ & $5,319,424 €$ & $5,185,369 €$ & 4 & $33.10 \%$ & $2-\mathrm{s}$ & 1.37 \\
\hline 700 & 500 & $6,758,266 €$ & $6,442,129 €$ & $6,301,347 €$ & 3 & $40.91 \%$ & $2-\mathrm{s}$ & 1.39 \\
\hline 840 & 600 & $7,951,380 €$ & $7,564,833 €$ & $7,417,324 €$ & 2 & $48.70 \%$ & $2-\mathrm{s}$ & 1.40 \\
\hline \multicolumn{9}{|c|}{ RATE 10\% } \\
\hline 280 & 200 & $3,397,160 €$ & $3,324,450 €$ & $3,170,943 €$ & 9 & $16.80 \%$ & $2-\mathrm{s}$ & 1.26 \\
\hline 420 & 300 & $4,590,274 €$ & $4,447,154 €$ & $4,286,921 €$ & 5 & $25.10 \%$ & $2-\mathrm{s}$ & 1.28 \\
\hline 560 & 400 & $5,783,388 €$ & $5,569,859 €$ & $5,402,899 €$ & 4 & $33.10 \%$ & $2-\mathrm{s}$ & 1.29 \\
\hline 700 & 500 & $6,976,502 €$ & $6,692,563 €$ & $6,518,876 €$ & 3 & $40.91 \%$ & $2-\mathrm{s}$ & 1.30 \\
\hline 840 & 600 & $8,169,616 €$ & $7,815,267 €$ & $7,634,854 €$ & 3 & $48.70 \%$ & $2-\mathrm{s}$ & 1.31 \\
\hline \multicolumn{9}{|c|}{ RATE 18\% } \\
\hline 280 & 200 & $3,742,138 €$ & $3,720,327 €$ & $3,514,805 €$ & $\mathrm{~N} / \mathrm{A}$ & $16.80 \%$ & $2-\mathrm{s}$ & 1.22 \\
\hline 420 & 300 & $4,935,252 €$ & $4,843,031 €$ & $4,630,782 €$ & 8 & $25.10 \%$ & $2-\mathrm{s}$ & 1.23 \\
\hline 560 & 400 & $6,128,366 €$ & $5,965,735 €$ & $5,746,760 €$ & 5 & $33.10 \%$ & $2-\mathrm{s}$ & 1.24 \\
\hline 700 & 500 & $7,321,480 €$ & $7,088,439 €$ & $6,862,737 €$ & 4 & $40.91 \%$ & $2-\mathrm{s}$ & 1.24 \\
\hline 840 & 600 & $8,514,594 €$ & $8,211,144 €$ & $7,978,715 €$ & 3 & $48.70 \%$ & $2-\mathrm{s}$ & 1.25 \\
\hline
\end{tabular}

